\title{
TANGGUNG JAWAB ORGAN PERSEROAN TERBATAS \\ DALAM KASUS KEPAILITAN
}

\author{
Siti Hapsah Isfardiyana \\ Fakultas Hukum Universitas Islam Indonesia \\ J1. Tamansiwa No. 158 Yogyakarta \\ Email: dianhapsah@gmail.com
}

\begin{abstract}
This paper aims to determine the responsibility of the Company's internal organs, namely the shareholders, Directors and Commissioners, if the Company suffered a loss to not be able to pay its debts to creditors and eventually bankrupted due to improper legal organ of the Company while the Company Indonesia adopts a separate entity and limited liability. However, limited liability can be changed to unlimited liability by piercing the corporate viel abusing his authority when organs Company. Authority Board of Directors and Commissioner based the principle of fiduciary duty. In this study the authors will use the method of normative conceptual approach that moved from the separate entity doctrine, limited liability, fiduciary duty, and piercing the corporate viel to look for suitability in laws and crustaceans. Accountability organs according to the Company's separate entity, limited liability, fiduciary duty, and piercing the corporate viel has been set in the laws and regulations. Each organ can be held accountable if found guilty of negligence or willful misconduct that led to the bankruptcy of the Company. Shareholders applied Article 3 paragraph (2) of the PT, the Board of Directors subject to Article 104 paragraph (2) of the PT, the Commissioner subject to Article 115 Paragraph (1) and paragraph (2) of the PT. Board of Directors and the Commissioner can also be charged with Article 1365 and 1366 of the Civil Code. In addition, the Criminal Code also can ensnare the Board of Directors and Commissioners with Article 398 and 399 of the Criminal Code.
\end{abstract}

Key words: responsibility, organ, bankruptcy

\begin{abstract}
Abstrak
Tulisan ini bertujuan untuk mengetahui tanggung jawab organ Perseroan yaitu pemegang saham, Direksi dan Komisaris, apabila Perseroan mengalami kerugian hingga tidak bisa membayar utang-utangnya kepada kreditor dan akhirnya dipailitkan akibat kesalahan organ Perseroan sedangkan hukum Perseroan Indonesia menganut sistem separate entity dan limited liability. Namun tanggung jawab terbatas dapat berganti menjadi tanggung jawab tidak terbatas melalui piercing the corporate viel ketika organ Perseroan menyalahgunakan wewenangnya. Wewenang Direksi dan Komisaris didasarkan prinsip fiduciary duty. Dalam penelitian ini penulis akan menggunakan metode normatif dengan pendekatan konseptual yang beranjak dari doktrin separate entity, limited liability, fiduciary duty, dan piercing the corporate viel untuk dicari kesesuiannya dalam peraturan perundang-udangan. Penelitian menunjukan bahwa pertanggungjawaban organ Perseroan menurut separate entity, limited liability, fiduciary duty, dan piercing the corporate viel telah diatur dalam peraturan perundang-undang. Masingmasing organ dapat dimintai pertanggungjawaban apabila terbukti melakukan kelalaian atau kesengajaan yang menyebabkan Perseroan pailit.Pemegang saham dapat dkenakan Pasal 3 ayat (2) UU PT, Direksi dikenakan Pasal 104 ayat (2) UU PT, Komisaris dikenakan Pasal 115 Ayat
\end{abstract}


(1) dan Ayat (2) UU PT . Direksi dan Komisari juga dapat dikenakan dengan Pasal 1365 dan 1366 KUHPerdata. Selain itu, KUHP juga dapat menjerat Direksi dan Komisaris dengan Pasal 398 dan 399 KUHP.

Kata kunci: tanggung jawab, organ, kepailitan

\section{Latar Belakang}

Perseroan merupakan wujud atau entitas (entity) yang terpisah dan berbeda dari pemlikinya dalam hal ini dari pemegang saham (separate and distinct from its owner). ${ }^{1}$ Kekayaan yang dimiliki Perseroan tidak dapat dimiliki atau dikuasai oleh para pemegang saham sehingga pemegang saham tidak berhak mengalihkan harta kekayaan Perseeroan kepada pihak kegita.Dengan demikian secara umum, eksistensi dan validitasnya, tidak terancam oleh kematian, kepailitan, penggantian atau pengunduran individu pemegang saham. ${ }^{2}$ Entitas terpisah (separate entity) memberikan keleluasaan kepada Perseroan tanpa tekanan dari pemegang saham dan tidak disalahgunakan oleh pemegang saham. Kekayaan yang dimiliki Perseroan menjadi milik sepenuhnya dari Perseroan sehingga Perseroan bertanggung jawab penuh atas kekayaan tersebut. Kewajiban yang timbul atas kerugian yang diterima Perseroan menjadi tanggung jawab Perseroan. Perseroan harus menggunakan kekayaannya sendiri tanpa menggunakan kekayaan pendiri atau pengurus Perseroan.

Separate entityakan memberikan tanggung jawab yang terbatas (limited liability). Pasal
3 ayat (1) Undang-Undang Nomor 40 Tahun 2007 tentang Perseroan (selanjutnya disebut UU PT) menyebutkan bahwa pemegang saham Perseroan tidak bertanggung jawab secara pribadi atas perikatan yang dibuat atas nama Perseroan dan tidak bertanggung jawab atas kerugian Perseroan melebihi saham yang dimiliki. Pemegang saham tidak dapat diminta pertanggungjawaban atas apa yang telah diperbuat oleh Perseroan. Pemegang saham hanya bertanggung jawab sebatas modal yang telah disetor kepada Perseroan dan tidak melebih modal yang telah disetor tersebut serta tidak dapat diminta pertanggungjawaban sampai kepada harta pribadi pemegang saham.Limited liability tidak hanya berlaku bagi pemegang saham tetapi juga berlaku bagi organ Perseroan yang lainnya yaitu Direksi dan Komisaris.Direksi dan Komisaris harus melakukan semua tugasnya sesuai dengan kewenangannya sesuai yang termaktub dalam perundang-undangan dan Anggaran Dasar Rumah Tangga Perseroan Terbatas (selanjutnya disebut AD PT).

Direksi Perseroan bertangggung jawab untuk mengelola Perseroan sesuai dengan maksud dan tujuan Perseroan dan mewakili Perseroan baik di dalam Pengadilan maupun

1 M. Yahya Harahap, Hukum Perseroan, Cetakan Ketiga, Edisi Ketujuh, Sinar Grafika, Jakarta, 2011, hlm. 57. 
di luar Pengadilan. Tanggung jawab yang diberikan kepada Direksi oleh Perseroan didasarkan atas kepercayaan (fiduciary duty). Fiduciary duty dijalankan oleh Direksi dengan kecakapan dan kehati-hatian (duty skill and care) berdasarkan ketentuan perundangundangan (statutory duties). Pasal 97 ayat (2) UU PT menyebutkan bahwa pengurusan Perseroan oleh Direksi wajib dilaksanakan dengan iktikad baik dan penuh tanggung jawab.

Komisaris bertanggung jawab mengawasi Perseroan dan memberi nasihat kepada Direksi Perseroan. Tanggung jawab Komisaris didasarkan pada prinsip yang sama dengan Direksi. Pemegang saham, Direksi dan Komisaris harus beriktikad baik dalam menjalankan wewenangnya masing-masing sesuai AD PT dan peraturan perundangundangan. Sehingga pemegang saham, Direksi dan Komisaris tidak dapat diminta pertangungjawaban atas tindakan Perseroan. Hal ini terjadi karena hukum Perseroan Indonesia menganut prinsip limited liability dan separate entity seperti yang telah di sebutkan di atas.

Perseroan sebagai badan hukum dapat diajukan pailit oleh kreditornya apabila harta Perseroan tidak mencukupi untuk memenuhi kewajibannya. Hal ini diatur dalam Pasal 2 ayat (1) Undang-Undang Nomor 37 Tahun 2004 tentang Kepailitan dan Penundaan Kewajiban Pembayaran Utang (selanjutnya disebut UU K). Menurut Pasal 21 UU K harta debitor pailit adalah seluruh harta kekayaan debitor baik yang sudah ada pada saat pernyataan pailit diucapakan maupun harta yang diperoleh selama kepailitan. Pelunasan atas utang-utang Perseroan diambilkan dari hasil penjualan harta kekayaan Perseroan bukan dari harta pemegang saham, Direksi ataupun Komisaris. Apabila harta Perseroan tidak mencukupi untuk menutup utang-utang Perseroan, para kreditor tidak dapat meminta penuhannya dari harta pemegang saham, Direksi maupun Komisaris Perseroan.

Berdasar penjelasan di atas, memunculkan pertanyaan bagaimana pertanggungjawaban organ Perseroan yaitu pemegang saham, Direksi maupun Komisaris, apabila Perseroan mengalami kerugian hingga tidak bisa membayar utang-utangnya kepada kreditor dan akhirnya dipailitkan akibat kesalahan organ Perseroan? Sedangkan hukum Perseroan Indonesia menganut sistem separate entity dan limited liability.

Untuk menjawab pertanyaan di atas penulis menggunakan metode normatif dengan pendekatan konseptual.Penulis mengggunakan konsep yang beranjak dari pandang-pandangan dan doktrin-doktrin yang ada dalam hukum bisnis untuk mengungkap permasalahan di atas. Adapun konsep dalam doktrin ialah pengenai separate entity, limited liability, fiduciary duty, dan piercing the corporate viel untuk dicari kesesuiannya dalam peraturan perundang-udangan yang berkaitan dengan permasalahan yang akan dipecahkan, yaitu Kitab Undang Undang Hukum Perdata (selanjutnya disebut 
KUHPerdata), Kitab Undang-Undang Hukum Dagang (selaanjutnya disebut KUHD), Kitab Undang-Undang Hukum Pindana (selanjutnya disebut KUHP) dan UU PT serta UU K. Sebagai bahan sekunder penulis menggunakan literatur berupa buku, jurnal, tulisan dari hasil karya ilmiah lainnya.

\section{Pembahasan}

Perseroan bearasal dari kata "perseroan" dan "terbatas". Kata "perseroan" berasal dari kata "sero" yang bermakna "saham". Sedangkan untuk kata "terbatas" bermakna keterbatasan dalam tanggung jawabnya. Tanggung jawab Perseroan hanya terbatas terhadap harta yang dimilikinya, bertanggung jawab tidak melebihi dan hanya sematamata bertanggung jawab terhadap harta yang terhimpun dalam Perseroan.Jadi, Perseroan adalah persekutuan yang terdiri dari sahamsaham dengan tanggung jawab yang terbatas, sebesar saham yang dimiliki oleh para pendirinya.Ini yang menjadikan Perseroan istimewah dan berbeda dengan badan hukum lainnya.

Tanggung jawab terbatas yang dimiliki Perseroan menjadikan Perseroan sebagai pilihan investasi yang lebih menguntungkan karena terbatasnya tanggung jawab yang akan diemban hanya sebesar modal yang disetor kepada Perseroan. Tanggung jawab terbatas atau disebut juga limited liability atau limitatief aansprakelijheid adalah suatu kondisi dimana pemegang saham atau shareholder atau aandeelhouder dari suatu Perseroan hanya bertanggung jawab sebatas pada sejumlah saham yang mereka miliki di Perseroan tersebut. ${ }^{4}$ Limited liability ini tidak hanya mengikat pemegang saham saja tetapi juga pengurus Perseroan yaitu Direksi dan Komisaris. Dengan adanya limited liability ini, pemegang saham ataupu direksi dan komisaris harus benar-benar jeli dalam membedakan mana tindakan sebagai organ Perseroan dan mana tindakannya sebagai perorangan. Semua tindakan pemegang saham, Direksi atau Komisaris suatu Perseroan telah ditentukan dalam peraturan perundang-undangan dan AD PT. Pemegang saham, Direksi ataupun Komisaris tidak diperbolehkan melakukan tindakan di luar kewenangan yang telah ditentukan dalam peraturan perundangundangan dan AD PT.

UU PT mendefinisikan bahwa Perseroan adalah badan hukum yang merupakan persekutuan modal, didirikan berdasarkan perjanjian, melakukan kegiatan usaha dengan modal dasar yang seluruhnya terbagi dalam saham dan memenuhi persyaratan yang ditetapkan dalam undang-undang ini serta peraturan pelaksanaannya. ${ }^{5}$ Perseroan sebagai badan hukum berarti Perseroan adalah

3 Rudhi Prasetya, Perseroan Teori dan Praktek, Sinar Grafika, Jakarta, 2011, hlm. 10.

4 Nindyo Pramono, Perbandingan Perseroan di Beberapa Negara, yang ditulis dalam rangka pelaksanaan dan pengembangan sistem hukum nasional Bandan Pembinaan Hukum Nasional Kementerian Hukum dan Hak Asasi Manusia R.I., hlm. 15.

5 Pasal 1 angka 1 UU PT. 
merupakan subjek hukum. Sebagai subjek hukum Perseroan dibertindak selayaknya subjek hukum lainnya yaitu manusia. Perseroan dapat bertindak seperti halnya seorang manusia pada umumnya karena badan hukum mempunyai persoonlijkheid, ${ }^{6}$ yaitu suatu kemampuan untuk menjadi subjek hukum dari hubungan hukum. Walaupun memiliki kemampuan hukum, kecakapan yang dimiliki Perseroan hanya terbatas dalam bidang harta kekayaan. Setiap keuntungan yang diperoleh oleh dari perbuatan hukum yang dilakukan Perseroan menjadi keuntungan pribadi Perseroan. Begitu juga apabila terjadi kerugian, kerugian tersebut menjadi beban Perseroan tanpa melibatkan orang-orang yang ada dalam perseroan tersebut baik para pendiri maupun para pengurusnya.Kontruksi badan hukum semacam itulah yang menurut Commen law dinamakan separate legal entity.

Pada dasarnya suatu Perseroan memiliki beberapa legal rights (hak dalam hukum), diantaranya:

a. Hak untuk memiliki atau menguasai properti (right to own property)

b. Hak untukr mengadakan atau membuat suatu perjanjian (right to a corporate seal)

c. Hak untuk menuntu dan dituntut di muka pengadilan (right to sue or to be sued) ${ }^{8}$

Perseroan sebagai badan hukum yang memiliki modal dasar yang merupakan jumlah modal yang dinyatakan dalam Akta Pendirian atau Anggaran Dasar Perseroan. Modal Perseroan tersebut terbagi atas saham (aandelen, share, stock).Saham tersebut kemudian dijual kepada orang perorang atau badan hukum (subjek hukum) yang lainnya, yang membayar saham tersebut kemudian disebut sebagai pemegang saham.Saham Perseroanmempunyai klasifikasi tertentu. Pemegang saham akan diberikan bukti kepemilikan saham. Bukti kepemilikan atas saham tunjuk berupa surat saham. Bukti kepemilikan saham atas nama diserahkan kepada para pemegang saham dan ditetapkan dalam AD PT sesuai dengan kebutuhan.

Pengurus Perseroan adalah organ-organ Perseroan. Masing-masing organ mempunai fungsi dan kewenangan masing-masing. Fungsi dan kewenangan tersebut telah diatur dalam peraturan perundang-undangan dan $\mathrm{AD}$ PT. yang dimaksud organ Perseroan adalah Rapat Umum Pemegang Saham (RUPS), Dewan Direksi dan Dewan Komisaris.Organ Perseroan inilah yang membantunya dalam berhubungan atau melakukan perbuatan hukum dengan pihak ketiga. Organ Perseroan bertugas mewakili Perseroan untuk dan atas nama Perseroan. Pasal 1655 KUHPerdata menyebutkan bahwa para pengurus badan hukum, bila tidak ditentukan lain dalam akta pendiriannya, dalam surat perjanjian atau dalam reglemen berkuasa untuk bertindak

6 Chidir Ali, Badan Hukum, Alumni, Bandung, 1987, hlm. 24.

7 Rudhi Prasetyo, Op.cit., hlm. 5.

8 Nindyo Pramono, Op.cit., hlm. 16. 
demi dan atas nama badan hukum itu, untuk mengikatkan badan hukum itu kepada pihak ketiga atau sebaliknya, dan untuk bertindak dalam sidang Pengadilan baik sebagai penggugat maupun sebagai tergugat. Badan hukum dalam hal ini adalah Perseroan, dapat melakukan perbuatan hukum maupun hubungan hukum melalui organ pengurusnya yaitu organ-organ Perseroan. Organ-organ Perseroan bertugas mewakili Perseroan sesuai dengan apa yang telah ditentukan dalam Anggaran Dasar Perseroan, dalam surat perjanjian dan dalam peraturan perundangundangan. Organ Perseroan berkewajiban mewakili Perseroan untuk melakukan hubungan hukum dengan pihak ketiga dan untuk mewakili Perseroan di dalam pengadilan baik sebagai pengggugat maupun sebagai tergugat.

Hukum Perseroan di Negara kita menganut sistem separate legal entity dan limited liability. Hal ini akan berakibat ketika terjadi kerugian terhadap Perseroan, baik pengurus maupun pendiri tidak dapat dimintai pertanggungjawaban. Pertanggungjawaban hanya dapat dimintakan dari harta pribadi Perseroan bukan harta pribadi pengurus atau pendiri.Kekayaan Perseroan terpisah dari para pendirinya dan para pengurusnya, yaitu para pemegang saham, Direksi dan Komisaris. Oleh karena itu, pemegang saham, Direksi maupun Komisaris tidak dapat dimintai pertanggungjawaban oleh pihak ketiga karena kerugian yang disebabkan oleh Perseroan. Begitu juga sebaliknya, kerugian yang diterima oleh pihak ketiga akibat tindakan pemegang saham, Direksi maupun Komisaris Perseroan yang dilakukannya secara pribadi bukan untuk Perseroan juga tidak dapat dimintakan kepada Perseroan.

Pasal 1131 KUHPerdata menyebutkan bahwasegala barang-barang bergerak dan tak bergerak milik debitor, baik yang sudah ada maupunyang akan ada, menjadi jaminan untuk perikatan-perikatan perorangan debitor itu.Ini memberikan arti bahwa setiap kreditor memiliki hak yang sama atas harta debitor (kesamaan kedudukan kreditor/ paritas creditorium). Pasal tersebut bertujuan memberikan jaminan rasa aman kepada kreditor atas perikatan yang dibuat dengan debitor. Apabila sewaktu-waktu debitor melakukan kesalahan kreditor dapat meminta ganti rugi dari debitor dan harta debitor sebagai jaminannya walaupun tidak diperjanjikan terlebih dahulu. Apabila debitor tidak dapat melunasi utang-utangnya, kreditor dapat mengajukan pailit kepada pengadilan Niaga setempat. Dan nanti yang akan membereskan harta debitor adalah kurator.

Selanjutnya Pasal 1132 menambahkan mengenai barang-barang debitor menjadi jaminan bersama bagi semua kreditor terhadapnya hasil penjualanbarang-barang itu dibagi menurut perbandingan piutang masingmasing kecuali bila di antarapara kreditor itu ada alasan-alasan sah untuk didahulukan. Setelah debitor dinyatakan pailitpasal 1132 KUHPerdata kekayaan debitor menjadi jaminan bersama para kreditornya dan 
kekayaan debitor harus dibagikan kepada para kreditornya secara proporsional kecuali ada alasan dari kreditor untuk didahulukan (asas pari passu prorata parte). Maksud dari alasan yang didahulukan adalah apabila ada kreditor yang memegang hak istimewah harus didahulukan pelunasannya. Apabila terdapat sisa dari penjualan barang yang dibebani hak istimewah tersebut nanti akan dikembalikan kepada kurator untuk kemudian dibagibagikan kepada kreditor yang lainnya.

Pelunasan atas semua utang Perseroan diambilkan dari hasil penjulan aset Perseroan. Harta pribadi pemegang saham, Direksi maupun Komisaris tidak dapat dimintakan untuk melunasi utang Perseroan apabila hasil penjualan harta Perseroan tidak cukup untuk melunasi utang Perseroan. Hal ini terjadi karena penerapan prinsip limited liability dan separate entity pada hukum Perseroan di Indonesia seperti yang telah dijelaskan di atas dan Pasal 1131 KUHPerdata yang telah menjelaskan bahwa kekayaan debitor (Perseroan) menjadi jaminan atas perikatan yang dilakukannya.

Namun, bagaimana jika terjadi tindakan pengurus dalam hal ini direksi dan komisaris atau tindakan dari pemegang saham yang bertindak atas nama Perseroan mengakibatkan Perseroan atau pihak ketiga mengalami kerugian yang berujung kepailitan? Pasal 3 ayat(2) UU PT menyebutkan bahwa ketentuan mengenai separate legal entity dan limited liability tidak berlaku apabilatabir Perseroan terkoyak (piercing the corporate viel). Piercing the corporate vielakan menghapus tanggung jawab terbatas dari pengurus dan pendiri Perseroan.

Istilah piercing the corporate veil kadangkadang disebut juga dengan istilah "lifting the veil" yang artinya menembus cadar atau membuka kerudung. ${ }^{9}$ Secara harafiah, istilah "piercing the corporate veil" berarti mengoyak tirai perusahaan. Sedangkan dalam ilmu hukum perusahaan, istilah piercing the corporate law merupakan suatu doktrin atau teori yang diartikan sebagai suatu proses untuk membebani tanggung jawab ke pundak orang atau perusahaan lain, atas perbuatan hukum yang dilakukan oleh suatu perusahaan pelaku (badan hukum), tanpa melihat kepada fakta bahwa perbuatan tersebut sebenarnya dilakukan oleh Perseroan pelaku tersebut. ${ }^{10}$ Nindyo Promono memberikan kelanjutan dari piercing the corporate viel dikenal dengan nama alter ego yaitu, jika seorang pemegang saham suatu Perseroan menguasai mayoritas saham pada Perseroan tertentu, kemudian Perseroan tersebut dipakai untuk tujuan-tujuan tertentu oleh pemegang saham tersebut melalui kuasaan mayoritasnya sebagai pemegang saham, maka secara tidak langsung Perseroan digunakan sebagai alat oleh pemegang saham untuk tujuan tertentu dari pemegang saham,

9 I. G. Rai Widjaya, Berbagai Peraturan dan Pelaksanaan Undang-undang di Bidang Usaha Hukum Perusahaan Pemakaian Nama PT, Tata Cara Mendirikan PT, Pendaftaran Perusahaan, TDUP \& SIUP, Kesaint Blanc, Jakarta, 2003, hlm. 146.

10 Munir Fuady, Doktrin-doktrin Modern dalam Corporate Law dan Eksistensinya dalam Hukum Indonesia, Cetakan Kedua, Citra Aditya Bakti, Bandung, 2010, hlm. 7. 
untuk mencapai keuntungan pribadi bahkan tidak tetutup dapat merugikan pihak ketiga. Kedua doktrin ini memberikan perlindungan hukum bagi pihak ketiga apabila pemegang saham, Direksi ataupun Komisaris bertindak di luar wewenangnya untuk kepentingan pribadi ataupun golongan sehinga merugikan pihak ketiga.

Piercing the corporate viel tidak dengan mudah diterapkan oleh pengadilan karena limited liability yang dimiliki Perseroan amat kuat dan tidak tergoyahkan begiu saja. Penerapan percing the corporate viel oleh pengadilan dilakukan dengan memperhatikan substansi atau kenyataan praktis pada bentuk formal dari Perseroan tersebut. ${ }^{11}$ Apabila terdapat kemungkinan Perseroan disalahgunakan atau dijadikan selubung oleh pemegang saham atau Direksi atau Komisaris maka pengadilan akan menyingkap tabir Perseroan tersebut dan membuka maksud terselubung organ Perseroan tersebut.

Berikut adalah organ Perseroan mulai dari wewenang sampai pertanggungjawaban dari masing-masing apabila terjadi kepailitan yang diakibatkan oleh tindakannya.

\section{A. RUPS}

Menurut Pasal 1 angka 4 UU PT RUPS adalah Organ Perseroan yang mempunyai wewenang yang tidak diberikan kepada Direksi atau Dewan Komisaris dalam batas yang ditentukan dalam undang-undang ini dan/atau anggaran dasar. RUPS dalam hal ini terdiri dari para pemegang saham yang menanamkan modalnya di Perseroan tersebut. Pemegang saham (shareholder) adalah para penyetor modal Perseroan dengan tanpa dibebani tanggung jawab kepengurusan Perseroan. Kepengurusan suatu Perseroan akan dilakukan oleh direksi dan komisaris.

Pemegang saham bertanggung jawab pada apa yang disetorkan atau bertangung jawab terbatas (limited liability), tidak bertanggung jawab atas kerugian Perseroan melebihi nilai saham yang telah diambilnya, tidak bertanggung jawab secara pribadi atas perikatan yang dibuat atas nama Perseroan. ${ }^{12}$

Konsep hukumPerseroan di Indonesia menganut sistemlimited liability (tanggung jawab yang terpisah). Hal ini berarti bahwa tindakan, perbuatan dan kegiatan Perseroan bukan tindakan pemegang saham dan kewajiban dan tanggung jawab Perseroan bukan kewajiban dan tanggung jawab pemegang saham. ${ }^{13}$ Konsep ini diberlakukan dengan maksud untuk melindungi pemegang saham dari kerugian yang lebih besar di luar apa yang telah mereka investasikan, pemegang saham mampu mengalihkan resiko kegagalan bisnis yang potensial kepada para kreditor Perseroan dan untuk mendorong investasi dan memfasilitasi akumulasi modal Perseroan. ${ }^{14}$

11 Chatamarrasjid Ais, Penerobosan Cadar Perseroan dan Soal-soal Aktual Hukum Perusahaan, Citra Aditya Bakti, Jakarta, 2004, hlm. 14.

12 I. G. Rai Widjaya, Op.cit., hlm. 143.

13 M. Yahya Harahap, Op.cit., hlm. 71.

14 Ridwan Khairandy, Perseroan Terbatas, Edisi Revisi, Total Media Yogyakarta, Jogjakarta, hlm. 260. 
Setiap kerugian yang dialami Perseroan akibat gagalnya Perseroan melakukan kewajibannya tidak menjadi tangggung jawab penuh dari pemegang saham.Pasal 3 ayat (1) UU PT menyebutkan bahwa pemegang saham Perseroan tidak bertanggung jawab secara pribadi atas perikatan yang dibuat atas nama Perseroan dan tidak bertanggung jawab atas kerugian Perseroan melebihi saham yang dimiliki atau hanya sebatas modal yang disetor kepada Perseroan.

Adapun wewenang RUPS menurut UU PT, antara lain:

a. Pasal 13 ayat (1) UU PT, menyatakan menerima atau mengambil alih semua hak dan kewajiban yang timbul dari perbuatan hukum yang dilakukan oleh calon pendiri atau kuasanya.

b. Pasal 14 ayat (4) UU PT, menyetujui perbuatan hukum Perseroan yang dilakukan oleh semua Direksi, semua Komisaris dan semua pendiri atas nama Perseroan yang dihadiri oleh semua pemegang saham.

c. Pasal 19 ayat (1) UU PT, menetapan perubahan Anggaran Dasar.

d. Pasal 38 ayat (1) UU PT, menyetujui pembelian kembali saham atau pengalihan saham yang telah dikeluarkan oleh Perseroan.

e. Pasal 39 ayat (1) UU PT menyerahkan kewenangan kepada Komisaris untuk menyetujui pelaksanaan RUPS untuk membeli atau mngalihan saham yang telah dikeluarkan Perseroan dalam jangka waktu paling lama satu tahun. f. Pasal 43 ayat (1) dan Pasal 44 ayat (1) UU PT, menetapan penambahan modal dan pengurangan modal Perseroan.

g. Pasal 64 ayat (1) jo Pasal 3 UU PT, menyetujui rencana kerja tahunan apabila AD PT menentukan demikian.

h. Pasal 69 ayat (1) UU PT, menyetujui laporan tahunan termasuk pengesahan laporan keuangan serta laporan tugas pengawasan Komisaris.

i. Pasal 71 ayat (1) UU PT, menetukan laba bersih termsuk penyisihan laba bersih yang akan digunkan sebagai cadangan

j. Pasal 92 ayat (1) UU PT, menetapkan pembagian tugas dan wewenang antaranggota Direksi.

k. Pasal 94 ayat (1) UU PT, mengangkat anggota Direksi.

1. Pasal 96 ayat (1) UU PT, menetapkan besarnya gaji dan tunjangan direksi.

m. Pasal 99 ayat (2) huruf c UU PT, menunjuk pihak yang akan mewakili Perseroan apabila Direksi atau Komisaris mempunyai benturan kepentingan.

n. Pasal 102 ayat (1) UU PT, memberi persetujuan Direksi untuk:

1) mengalihkan kekayaan Perseroan; atau

2) menjadikan jaminan utang kekayaan Perseroan; persetujuan ini diperlukan apabila lebih dari 50\% (lima puluh persen) jumlah kekayaan bersih Perseroan dalam1 (satu) transaksi atau lebih, baik yang berkaitan satu sama lain maupun tidak. 
o. Pasal 104 ayat (1) UU PT, memberi persetujuan kepda Direksi untuk mengajukan permohonan pailit atas Perseroan sendiri ke Pengadilan Niaga setempat.

p. Pasal 105 ayat (2) UU PT, memberhentikan Direksi.

q. Pasal 106 ayat (7) UU PT, menguatkan keputusan pemberhentian sementara, anggota Direksi yangbersangkutan diberhentikan untuk seterusnya.

r. Pasal 111 ayat (1) UU PT, menggangkat Komisaris.

s. Pasal 113 UU PT, menetapkan besarnya gaji dan honorarium dan tunjangan Komisaris.

t. Pasal 120 ayat (2) UU PT, mengangkat Komisaris Independen.

u. Pasal 123 ayat (3) UU PT, memberi persetujuan rancangan penggabungan

v. Pasal 127 ayat (1) UU PT, memberi persetujuan mengenai penggabungan, peleburan, pengambilalihan atau pemisahan.

w. Pasal 142 ayat (1) huruf a UU PT, memberi keputusan atas pembubaran Perseroan.

x. Pasal 143 ayat (1) UU PT, menerima pertanggungjawaban likuidator atas penyelesaian likuidasi.

Tidak selamanya limited liability dapat menjadi perisai bagi para pemegang saham dalam tanggung jawab atas kerugian Perseroan. Ketika pemegang saham berbuat dengan iktikad tidak baik atau tindakan dari pemegang saham merugikan Perseroan limited liability dapat disingkirkan atau ditembus dengan mengoyak tabir Perseroan atas perisai limited liability tersebut dengan menggunakan doktrin piercing the corporate veil. Apabila tanggung jawab (limited liability) tersebut terkoyak dan perisai dapat tertembus maka tanggung jawab pemegang saham tertembus dan dapat menjangkau harta pribadi.Pasal 3 ayat (2) UU PT memberikan tempat untuk diberlakukannya Piercing the corporate veil. Menurut UU PT piercing the corporate veildapat diberlakukan ketika:

a. persyaratan Perseroan sebagai badan hukum belum atau tidak terpenuhi.

b. pemegang saham yang bersangkutan baik langsung maupun tidak langsung dengan iktikad buruk memanfaatkan Perseroan untuk kepentingan pribadi.

c. pemegang saham yang bersangkutan terlibat dalam perbuatan melawan hukum yang dilakukan oleh Perseroan atau

d. pemegang saham yang bersangkutan baik langsung maupun tidak langsung secara melawan hukum menggunakan kekayaan Perseroan, yang mengakibatkan kekayaan Perseroan menjadi tidak cukup untuk melunasi utang Perseroan.

Dalam kaitannya dengan kepailitan suatu Perseroan penerapan piercing the corporate veil ini sangat membantu karena tidak jarang pemegang saham menyalahgunakan tanggung jawab terbatas (limited liability) yang dimandatkan undang-undang untuk kepentingan sendiri atau kelompok tertentu sehingga merugikan pihak lain. Piercing the 
corporate veil yang dianut UU PT memiliki konsep yang sama dengan misbruik van rechtpersonen yang dianut oleh Belanda dalam Wet Op Misbruik van Rechspersonen. ${ }^{15}$ Peraturan Belanda tersebut memuat mengenai: manakala suatu badan hukum jatuh pailit sehingga kekayaan badan tidak cukup membayar maka lunas utangnya dan ternyata pengurus nyata-nyata tidak melaksanakan tugasnya secara pantas (wanner het bestuur zjin taak kennelijk on behoorlijk heft vervuld), dan dapat diperkirakan ketidakpantasan pengurus dalam menjalankan tugasnya itu (en aanemelijk is dat dit een belaangrijke oorzaak is van het faillisement), maka pengurus harus ikut bertanggung jawab secara pribadi, artinya menjadi tanggung jawab pribadi atas sisa utang yang masih belum cukup terbayar dari harta kekayaan badan yang bersangkutan, dan dalam hal ini yang dimaksud dengan pengurus yang harus ikut bertanggung jawab secara pribadi itu bukan saja dalam arti formal di atas kertas menurut statute atau akta, akan tetapi dengan pengertian pengurus di sini harus ditafsirkan termasuk pula orang-orang yang menurut kenyataan menentukan dalam pengambilan keputusan kebijakan perusahaan yang bersangkutan. Yang dimaksud dengan "orang-orang yang menurut kenyataan menentukan dalam mengambil keputusan kebijaksaan perusahaan yang bersangkutan", dapat berupa para komisaris atau para pemegang saham. ${ }^{16}$

Tidak tertutup kemungkinan tanggung jawab pemegang saham yang hanya sebesar setoran atas seluruh saham yang dimilikinya kemungkinan terhapus karena terkoyaknya tabir Perseroan. Apabila terbukti, antara lain terjadi pencampuran harta kekayaan pribadi pemegang saham dan harta kekayaan Perseroan sehingga Perseroan didirikan semata-mata sebagai alat yang dipergunakan pemegang saham untuk memenuhi tujuan pribadinya sehingga Perseroan mengalami kepailitan serta terbukti penyebab kepailitan tersebut adalah pemegang saham maka pemegang saham dapat dimintai pertanggung jawaban sampai pada harta pribadi.

\section{B. Direksi}

Pasal 1 angka 5 UU PT menyebutkan Direksi suatu Perseroan berwenang dan bertanggung jawab penuh atas pengurusan Perseroan untuk kepentingan Perseroan, sesuai dengan maksud dan tujuan Perseroan serta mewakili Perseroan, baik di dalam maupun di luar pengadilan sesuai dengan ketentuan anggaran dasar. Tugas direksi Perseroan dijelaskan dalam Pasal 92 Ayat (1), (2) dan Pasal 97 Ayat (2) UU PT yaitu menjalankan pengurusan Perseroan untuk kepentingan Perseroan dan sesuai dengan maksud dan tujuan Perseroan sesuai dengan

15 Hadi Subhan, Hukum Kepailitan Prinsip, Norma dan Praktik di Peradilan, Cetak Ketiga, Edisi Pertama, Kencana, Jakarta, 2012, hlm. 250.

16 Rudi Prasetya, Ibid., hlm. 250-251. 
kebijakan yang dipandang tepat, dalam batas yang ditentukan dalam undang-undang dan/ atau anggaran dasar dengan iktikad baik dan penuh tanggung jawab. Saat direksi mewakili Perseroan baik di dalam maupun di luar pengadilan disebut sebagai tugas representasi sedangkan saat direksi mengurus Perseroan dengan menjalankan kepemimpinan Perseroan, disebut sebagai tugas manajemen.

Direksi dalam menjalankan reprentasi di luar pengadilan diantaranya adalah melakukan kontrak atau transaksi bisnis dengan pihak ketiga, mewakili Perseroan untuk menandatangi kontrak tersebut, mewakili Perseroan untuk menghadap pejabat negara dan masih banyak lagi yang lainnya. Mewakili Perseroan di dalam maupun di luar pengadilan dapat dilakukan dengan cara sebagai berikut:

a. Dilakukan sendiri

b. Dilakukan pegawainya yang ditunjuk untuk itu

c. Dilakukan komisaris jika Direksi berhalangan, sesuai AD PT

d. Dilakukan oleh pihak ketiga sebagai agen dari Perseroan. ${ }^{17}$

Dalam melakukan tugas-tugasnya Direksi dapat meminta orang lain untuk mewakilinya. Perwakilan tersebut dapat diberikan kepada pihak internal Perseeroan maupun kepad pihak eksternal Perseroan. Dalam perwakilan tersebt berlaku prinsip perwakilan atau keagenan. Salah satunya ialah delegatus nonpotest delegare, yaitu seseorang yang sudah menerima pendelegasian tugas tertentu tidak dapat mendelgasikan lagi tugas tersebut tanpa sepengetahuan pihak pertama yang mendelegasikan tugas tersebut. Jadi apabila Direksi meminta seseorang untuk membantu melaksananakan tugas-tugasnya seseorang tersebut tidak boleh melimpahkan tugas yang diberikan Direksi tersebut tanpa seijin Direksi yang bersangkutan. Untuk tugas pengurusan Perseroan dilakukan Direksi dalam pengurusan kegiatan sehari-hari.

Pengurusan oleh direksi dibatasi oleh Pasal 92 ayat (2) UU PT, yang mana pada pasal tersebut disebutkan bahwa kewenangan pengurusan Perseroan oleh Direksi sesuai dengan kebijakan yang dianggap tepat yang telah ditentukan dalam AD PT dan peraturan perundang-undangan.

Kepengurusan direksi dapat dibedakan menjadi perbuatan beheren dan perbuatan beschickking atau perbuatan van eigendom. Perbuatan beheren yaitu pengurusan dalam arti sempit yang merupakan wewenang murni dan dapat dilakukan sehari-hari.Sedangkan perbuatan beschickking merupakan berbuatan kepemilikan yang memerlukan persetujuan dari organ lainnya.

Begitu luas kewenangan dan tangggung jawab direksi suatu Perseroan sehingga direksi wajib melakukan tugasnya dengan iktikad abaik (good faith) dan penuh tanggung 
jawab. Direksi sebagai pengelola Perseroan merupakan pemegang amanah (fiduciary) dari pemegang saham. Fiduciary yang dimiliki oleh direksi menyebabkan direksi mempunyai kewenangan yang sangat tinggi. Oleh karena itu, seorang direksi dituntut harus dapat mempunyai kepedulian dan kemampuan (duty of care and skill), iktikad baik, loyalitas dan kejujuran terhadap perusahaannya dengan derajat yang tinggi (high degree). ${ }^{18}$

Direksi dalam menjalankan tugas pengurusan dan mewakili Perseroan di depan pengadilan maupun di luar pengadilan harus dengan penuh tanggung jawab untuk kepentingan Perseroan disebut fiduciary dutiy. Fiduciary duty dijalankan oleh direksi dengan cara:

a. Dilakukan dengan iktikad baik (bona fides).

b. Dilakukan dengan proper purpose

c. Dilakukan dengan kebebasan yang bertanggung jawab (unfettered discretion).

d. Tidak memiliki benturan kepentingan (conflict of duty and interest). ${ }^{19}$

Iktikad baik Direksi dapat dilihat ketika Direksi benar-benar mementingkan kepentingan Perseroan, shareholderdan stakeholder. Proper purpose (tujuan yang benar) dijalankan dengan menaati AD PT, hukum dan kepentingan umum. Menurut M. Yahya Harahap, ada beberapa aspek pengurusan yang wajib dilakukan dengan iktikad baik, yaitu:

a. Wajib dipercaya (fiduciary duty) yakni selama dapat dipercaya (must always bonafide) dan selamnya harus jujur (must always honest).

b. Wajib melaksananakan pengurusan untuk tujuan yang wajar atau layak (duty to act for proper purpose)

c. Wajib menaati peraturan perundangundangan (statutory duty or duty obedience)

d. Wajib loyal terhadap Perseroan (loyalty duty), tidak menggunkan dana dan aset Perseroan untuk kepentingan Pribadi, wajib merahasiakan segala informasi (confidential duty of information) Perseroan.

e. Wajib menghindari kepentingan pribadi dengan kepentingan Perseroan (must avoid conflict of interest).

Benturan kepentingan bisanya terjaadi ketika melakukan kontrak dengan perusahaan lain, terdapat keuntungan rahasia, kompetisi dengan perusahaan lain dan terjadi penyalahgunaan kepercayaan (abuse of confidence) dari aset Perseroan, rahasia dagang dan informasi rahasia.

Direksi wajib melaksanakan pengurusan dengan penuh tangung jawab, yang meliputi aspek: ${ }^{20}$ 
a. Wajib sesakma dan hati-hati melakukan pengurusan (the duty of the due care), yakni kehati-hatian yang biasa dilakukan orang (ordinary prudent person) dalam kondisi yang wajar atau disebut dengan kehati-hatian yang wajar (reasional care).

b. Wajib melaksanakan pengurusan secara tekun (duty to be diligent), yakni terus menerus secara wajar menumpahkan perhatian atas kejaian yang menimpa Perseroan.

c. Ketekunan dan keuletan wajib disertai kecakapan dan keahlian (duty to display skill) sesuai dengan ilmu pengetahuan dan pengetahuan yang dimilikinya.

Seorang direksi tidak akan bertanggung jawab karena salah dalam mengambil keputusan (mere errors of judgement) ketika direksi menjalankan tugasnya dengan iktikad baik dan penuh kehati-hatian. Hakim dalam hal ini tidak diperbolehkan melakukan penilaian bisnis yang berbentuk second guess ${ }^{21}$ terhadap keputusan bisnis yang diambil oleh direksi sesuai dengan teori keputusan bisnis (business judgement rule). Walaupun setiap keputusan direksi yang diambil dilindungi oleh business judgement rule, direksi tetap harus beriktikad baik, berhati-hati dan penuh loyalitas dalam menjalankan kepengurusan Perseroan.

Perseroan telah memberikan kepercayaan yang besar kepada direksi untuk menjalakan kepengurusan Perseroan dengan harapan tujuan Perseroan tercapai sesuai dengan yang tercantum dalam peraturan perundangundangan dan Angagaran Dasar Perseroan. Apabila direksi dengan sengaja berbuat melampaui kewenangannya maka dapat dikenakan ultra vires (pelampauan kewenangan Perseroan).Ultra vires diterapkan pada kegiatan yang dilarang AD PT dan perbuatan yang melampaui kewenangan yang diberikan oleh AD PT dan peraturan perundang-undangan serta perbuatan yang yang bertentangan dengan peraturan yang berlaku dan ketertiban umum. Pada dasarnya setiap tindakan ultra vires batal demi hukum karena perbuataan tersebut tidak mempunyai dasar yuridis, Perseroan tidak mempunyai kewenangan baik dari AD PT ataupun peraturan perundang-undangan yang berlaku.

Tuntutan keadilan menyebabkan beberapa perbuatan yang digolongkan dalam $u$ ltra vires tidak dibatalkan, yaitu:

a. Restitusi (pengembalian) aset yang sudah dialihkan dengan transaksi yang ultra vires tidak mungkin dikembalikan lagi.

b. Perseroan telah diberi ganti rugi terhadap kerugian yang terjadi karena transaksi ultra vires tersebut.

c. Pembatalan transaksi akan merugikan hak yang didapat tidak secara gratis dari pihak ketiga yang beriktikad baik di luar kontrak.

d. Transaksi yang mengandung ultra vires tersebut telah diratifikasi oleh RUPS atau oleh resolusi dari pemegang saham. ${ }^{22}$

Tolok ukur dari sebuah tindakan Direksi 
tidak termasuk ultra vires ialah ketika tindakan tersebut termasuk dalam kewenangan atau maksud dan tujuan Perseroan. Direksi dianggap mengetahui segala perbuatannya apakah termasuk dalam ultra vires meskipun sebenarnya dia tidak mengetahui hal tersebut. Hal ini disebut sebagi pengetahuan konstruktif (constructive notice). Akibat hukum dari constructive notice adalah:

a. Direksi harus menaati transaksi ultra vires yang telah dibuatnya.

b. Jika dengan transaksi tersebut ada keuntungan yang didapat oleh Direksi, keuntungan tersebut haruslah diserahkan kepada Perseroan.

c. Direksi secara pribadi harus mengganti kerugian kepada pihak ketiga yang telah dirugikan oleh tindakan ultra vires tersebut.

d. Direksi secara pribadi harus mengganti kerugian atas kerugian Perseroan karena adanya tindakan ultra vires tersebut. ${ }^{23}$

Ganti kerugian yang disebutkan di atas didasarkan pada piercing the corporate viel. Menurut Munir Fuady selain karena ultra vires, Direksi juga dapat dikenakan piercing the corporate viel dalam hal:

a. Direksi tidak melaksanakan fiduciary duty kepada Perseroan.

b. Dokumen perhitungan tahunan tidak benar.

c. Direksi bersalah dan menyebabkan Perseroan pailit. d. Permodalan yang tidak layak.

e. Perseroan beroperasi secara tidak layak.

Terkait dengan kasus kepailitan direksi dapat dimintai pertanggungjawaban apabila memenuh unsur-nsur sebagai berikut:

a. Terdapat unsur kesalahan (kesengajaan) atau kelalaian dari direksi (dengan pembuktian biasa).

b. Untuk membayar utang dan ongkosongkos kepailitan, haruslah diambil terlebih dahulu dari aset-aset perseroan. Apabila aset perseroan tidak memenuhi barulah diambil dari aset direksi pribadi.

c. Diberlakukan pembuktian terbalik (omkering van bewijslast) bagi anggota direksi yang dapat membutikan bahwa kepailitan perseroan bukan karena kesalahan (kesengajaan) atau kelalaian. ${ }^{24}$ Pasal 104 ayat (2) UU PT menegaskan bahwa dalam hal kepailitanterjadi karena kesalahan atau kelalaian Direksi dan harta pailit tidak cukup untuk membayar seluruh kewajiban Perseroan dalam kepailitan tersebut, setiap anggota Direksi secara tanggung renteng bertanggung jawab atas seluruh kewajiban yang tidak terlunasi dari harta pailit tersebut. Pasal 104 ayat (2) UU PT jelas mengakui bahwa Direksi harus bertanggung jawab atas kepailitan Perseroan yang dipimpinnya. Pertanggungjawaban Direksi diberlakuan atas kepailitan yang menimpa Perseroan tersebut apabila kepailitan tersebut terjadi karena kesalahan atau kelalainnya. Dan apabila hasil 
penjualan harta perseroan tidak cukup untuk menutup semua utang Perseroan dan biayabiaya Perseroan, Direksi harus bertanggung jawab sampai kepada harta pribadi Direksi yang bersangkutan.

Menurut Sutan Remi Syahdeni, kesalahan adalah kesengajaan. Sedangkan kelalaian (culpa) terdapat tiga tingkatan yaitu lata culpa atau kelalaian berat, levis culpa atau kelalaian wajar, dan levissima culpa atau kelalaian ringan. Dalam Pasal 104 ayat (2) UU PT tidak menjelaskan kelalaian seperti apa yang mengakibatkan Direksi bertanggung jawab secara pribadi atas kepailitan Perseroan yang dipimpinnya. Jadi, Direksi tetap harus bertanggung jawab atas kelalainnya tanpa melihat hal itu termasuk kelalain berat ataupun kelalaian ringan. Menurut Sutan Remi Syahdeni, Direksi Perseroan dalam menjalankan tugasnya hanya bertanggung jawab apabila kelalaian yang dilakukannya adalah kelalaian berat (gross negligence). ${ }^{25}$

Direksi juga dapat dikenakan dengan pasal 1365 dan 1366 KUHPerdata.Kedua pasal tersebut merupakan dasar seseorang untuk dapat dikenakan berdasarkan prinsip perbuatan melawan hukum (onrechtmatige daad).Dalam pasal tersebut ditegaskan mengenai seseorang yang melanggar hukum dalam hal ini UU PT dan AD PT yang bersankutan wajib mengganti kerugian kepada pihak yang dirugikan karena kesembronoannya atau kelalaiannya.

Menurut Purnadi Purwacaraka, seorang Direksi dapat dikatakan melakukan perbuatan melawan hukum (PMH) karena direksi dengan sengaja melakukan suatu perbuatan yang menimbulkan kerugian pada orang lain atau dengan sengaja diam saja, sedangkan ia sudah mengetahui bahwa ia harus melakukan suatu perbuatan untuk tidak merugikan orang lain dikatan sebagai penyelewengan perdata.

Selain dapat dikenakan dengan perkara perdata, kelalaian maupun kesalahan dari direksi tersebut dapat juga dikenakan dengan ketentuan pidana melalui Pasal 398 dan Pasal 399 KUHP. Secara singkat, Pasal 398 KUHP menjelaskan bahwa direksi maupun komisaris dapat ditutut pidana penjara selama satu tahun empat bulan (1tahun 4bulan) apabila direksi maupun komisaris menyebabkan kerugian bagi Perseroan maupun pihak lain. Sedangkan menurut Pasal 399 KUHP direksi maupun komisaris dapat dikenakan dengan pidana penjara selama tujuh tahun (7 tahun) apabila yang bersangkutan membuat kecurangan dengan mengurangi hak-hak para kreditor dan lalai dalam membuat pembukuan sebagaimana diwajibkan dalam anggaran dasar dan peraturan perundang-undangan.

\section{Komisaris}

Menurut UU PT Pasal 1 angka 6 dewan Komisaris adalah Organ Perseroan yang bertugas melakukan pengawasan secara umum dan/atau khusus sesuai dengan anggaran dasar serta memberi nasihat kepada Direksi. Tugas Komisaris ditentukan dalam Pasal 108 UU PT, yaitu melakukan pengawasan atas kebijakan 
pengurusan, jalannya pengurusan pada umumnya, baik mengenai Perseroan maupun usaha Perseroan, dan memberi nasihat kepada Direksi untuk kepentingan Perseroan dan sesuai dengan maksud dan tujuan Perseroan.

Komisarisbertugasmelakukanpengawasan dan memberikan nasihat kepada direksi sesuai dengan maksud dan tujuan Perseroan. Hal ini dilakukan agar direksi maupun Perseroan tidak melakukan pelanggaran hukum atau merugikan baik Perseroan sendiri, pemegang saham (shareholders) maupun pihak lain. Fungsi pengawasan ini diwujudkan dengan dua level yaitu, level performance dan level conformance. Level performance adalah fungsi pengawasan oleh Komisaris untuk memberikan pengarahan dan petunjuk kepda Direksi dan RUPS. Sedangkan untuk level conformance berupa pelaksanaan kegiatan pengawasan agar dipatuhi dan dilaksanakan terhadap pengarahan dan petunjuk yang telah diberikan atau ketentuan yang ada dalam peraturan perundang-undangan.

Munir Fuady menjelaskan mengenai beberapa pedoman yuridis pengawasan Komisaris, yaitu:

Pengawasan dilakukan oleh Komisaris baik diminta mapun tidak diminta oleh Direksi dan RUPS

a. Pengawasan tidak boleh berubah menjadi tugas eksekutif yang seharusnya dilakukan oleh Direksi.

b. Pengawasan dilakukan terhadap putusan yang sudah diambil (ex post facto) atau terhadap putusan yang akan diambil (preventive basisi). c. Pengawasan bukan hanya menerima laporan dari Direksi atau RUPS tetapi dapat juga merupakan pengambilan tindakan yang bersifat korektif.

d. Pengawasa bukan hanya menyetujui atau tidak menyetujui tindakan-tindakan yang memerlukan persertujuan Komisaris sseperti yang terperinci dalam AD PT tetapi juga pengawasasan terhadap semua aspek bisnis dan aspek korporat Perseroan.

e. Pengawasan Komisaris bukan hanya untuk mengawasi Direksi tetapi juga untuk mengawasi para pemegang saham. Pengawasan ditujukan untuk melindungi kepentingan Perseroan, stakeholder, termasuk karyawan dan lingkungan Perseroan serta masyarakat.

Pengawasan komisaris antara lain ditujukan pada:

a. Melakukan audit keuangan.

b. Pengawasan atas organisasi Perseroan Terbatas.

c. Pengawasan terhadap personalia.

Dalam UU PTtidak terdapat penjelasan terperinci mengenai pemberian nasihat kepada direksi oleh komisaris.Namun, menurut $\mathrm{M}$. Yahya Harap pemberian nasihat komisaris kepada direksi cakupannya sangatlah luas. Komisaris dapat menyampaikan pendapat atu member pertimbangan yang layak dan tepat kepada direksi.Bahkan dapat menyampaikan ajaran yang baik maupun petunjuk, peringatan, atau teguran yang baik. ${ }^{26}$ 
Seperti halnya direksi, komisaris suatu Perseroan juga diwajibkan untuk beriktikad baik dan penuh dengan kehati-hatian dalam menjalankan tugasnya. Itikad baik yang harus dilakukan oleh Komisaris tidak berbeda dengan itikad baik yang dilakukan oleh Direksi. Dimana Komisaris juga harus dipercaya dengan kejujurannya, pengawasan dan nasihat dilakukan secara wajar, mematuhi peraturan perundang-undangan, loyal terhadap Perseroan dan menghindari benturan kepentingan dengan Perseroan.

Benturan kepentingan dengan Perseroan dapat dihindari oleh Komisaris dengan cara:

a. Tidak menggunakan informasi Perseroan untuk kepentingan pribadi.

b. Tidak menggunkaan uang dan kekayaan Perseroan untuk kepantingan pribadi.

c. Tidak menggunakan posisinya untuk memperoleh keuntungan pribadi.

d. Tidak mengambil sebagian keuntungan Perseroan untuk kepentingan pribadi.

e. Tidak melakukan transaksi apapun dengan Perseroan.

f. Tidak melakukan persaingan dengan Perseroan. $^{27}$

Direksi diberikan kepercayaan oleh Perseroan untuk mengawasi dan memberikan nasihat kepada direksi. Dari hal ini dapat disimpulkan bahwa dalam menjalankan tugasnya komisaris juga harus menggunakan prinsip fiduciary dutysama halnya dengan

26 M. M. Yahya Harahap, Op.cit., hlm. 440.

27 Ibid., hlm. 458.

28 Munir Fuady, Op.cit., hlm. 26. direksi. Komisaris juga memegang amanah (fiduciary) dari Perseroan untuk benar-benar memperhatikan Perseroan dengan cara melakukan pengawasan dan nasihat secara sungguh-sungguh dengan kepedulian, kehatihatian, iktikad baik, jujuran dan sesuai dengan ketrampilan yang dimiliki.

Pasal 114 ayat (3) UU PT menjelaskan mengenai pelanggaran fiduciary duty juga berakibat pada tanggung jawab komisaris secara pribadi atas kerugian Perseroan apabila yang bersangkutan bersalah atau lalai menjalankan tugasnya.Pengawasan dan nasihat wajib dilakukan oleh Komisaris dengan kehati-hatian yaitu tidak sembrono dan tidak lalai dengan memperhatikan pertimbangan yang wajar. Kesalahan dan kelalaian menjadi dasar penerapan piercing the corporate viel pada Komisaris sehingga Komisaris dibebani tanggung jawab tidak terbatas sampai kepada harta pribadi Komisaris.

Piercing the corporate viel diberlakukan kepada Komisaris dalam hal sebagai berikut:

a. Komisaris tidak melaksakan fiduciary duty.

b. Dokumen perhitungan tahunan tidak benar.

c. Kepailitan Perseroan karena kelalian komisaris. $^{28}$

Apabila komisaris merasa tidak bersalah, komisaris dapat melakukan pembuktian terbalik sesuai ketentuan dalam Pasal 114 
Ayat (5) UU PT, yaitu:

a. telah melakukan pengawasan dengan itikad baik dan kehati-hatian untuk kepentinganPerseroan dan sesuai dengan maksud dan tujuan Perseroan.

b. tidak mempunyai kepentingan pribadi baik langsung maupun tidak langsung atas tindakan pengurusan Direksi yang mengakibatkan kerugian dan

c. telah memberikan nasihat kepada Direksi untuk mencegah timbul atau berlanjutnya kerugian tersebut.

Namun, apabila komisaris benar-benar melanggar fiduciary duty Pasal 114 Ayat (6) UU PT telah memberikan akses kepada pemegang saham untuk menuntut komisaris tersebut. Bunyi pasal tersebut adalah atas nama Perseroan, pemegang saham yang mewakili paling sedikit 1/10 (satu persepuluh) bagian dari jumlah seluruh saham dengan hak suara dapat menggugat anggota Komisaris yang karena kesalahan atau kelalaiannya menimbulkan kerugian pada Perseroan ke pengadilan negeri.

Komisaris dalam kaitannya dengan kepailitan sebuah Perseroan telah diatur dalam Pasal 115 Ayat (1) dan Ayat (2) UU PT yaitu Dalam hal terjadi kepailitan karena kesalahan atau kelalaian Dewan Komisaris dalam melakukan pengawasan terhadap pengurusan yang dilaksanakan oleh Direksi dan kekayaan Perseroan tidak cukup untuk membayar seluruh kewajiban Perseroan akibat kepailitan tersebut, setiap anggota Dewan Komisaris secara tanggung renteng ikut bertanggung jawab dengan anggota Direksi atas kewajiban yang belum dilunasi. Tanggung jawab sebagaimana dimaksud pada ayat (1) berlaku juga bagi anggota Dewan Komisaris yang sudah tidak menjabat 5 (lima) tahun sebelum putusan pernyataan pailit diucapkan.

Untuk Anggota Dewan Komisaris yang merasa tidak bersalah harus membuktikan hal-hal berikut:

a. kepailitan tersebut bukan karena kesalahan atau kelalaiannya.

b. telah melakukan tugas pengawasan dengan iktikad baik dan kehati-hatian untuk kepentingan Perseroan dan sesuai dengan maksud dan tujuan Perseroan.

c. tidak mempunyai kepentingan pribadi, baik langsung maupun tidak langsung atas tindakan pengurusan oleh Direksi yang mengakibatkan kepailitan dan

d. telah memberikan nasihat kepada Direksi untuk mencegah terjadinya kepailitan. ${ }^{29}$

Sama halnya dengan direksi, penuntutan terhadap komisaris atas kasus kepailitan juga dapat dasarkan pada Pasal 1365 dan1366 KUHPerdata. Pasal tersebut menjerat komisaris karena komisaris telah lalai dan karena kesalahannya telah menyebabkan pihak lain yaitu shareholder dan stakeholder mengalami kerugian.

\section{Simpulan}


Limited liability yang dimiliki organ Perseroan ternyata tidak mutlak. Hal itu dapat disimpangi dengan pengoyak tabir Perseroan (piercing the corporate viel). Begitu juga pelanggaran terhadap fiduciary duty akan berakibat pada penerapan piercing the corporate viel.Pasal 97 Ayat (3) UU PT menyebutkan apabila direksi lalai dan terbukti bersalah menjalankan tugasnya maka berlakulah tanggung jawab penuh secara pribadi bagi direksi.Pasal 114 ayat (3) UU PT menjelaskan mengenai pelanggaran fiduciary duty juga berakibat pada tanggung jawab komisaris secara pribadi atas kerugian Perseroan apabila yang bersangkutan bersalah atau lalai menjalankan tugasnya,
Terkait kasus kepailitan masing-masing organ dapat dimintai pertanggungjawaban apabila terbukti melakukan kelalaian atau kesengajaan yang menyebabkan Perseroan pailit. Adapuntanggung jawab masing-masing organ adalah sebagai berikut:

a. RUPS dalm hal ini pemegang saham. Diberlakukan Pasal 3 ayat (2) UU PT.

b. Direksi, yang tertuang dalam Pasal 104 ayat (2) UU PT.

c. Komisaris, yang tertuang dalamPasal 115 Ayat (1) dan Ayat (2) UU PT.

Selain UU PT direksi dan komisari juga dapat dikenakan denganPasal 1365 dan 1366 KUHPerdata danPasal 398 dan 399 KUHP.

\section{DAFTAR PUSTAKA}

\section{Buku}

Chamarrasjid Ais, 2004, Penerobosan Cadar Perseroan dan Soal-soal Aktual Hukum Perusahaan, Citra Aditya Bakti, Jakarta.

Chidir Ali, 1987, Badan Hukum, Bandung, Alumni.

Hadi Subhan, 2012, Hukum Kepailitan Prinsip, Norma dan Praktik di Peradilan, Cetak Ketiga, Edisi Pertama, Kencana, Jakarta.

H. Zaeni Asyhadie dan Budi Sutrisno, 2012,

Hukum Perusahaan dan Kepailitan, Erlangga, Jakarta.
I. G. Rai Widjaya, 2003, Berbagai Peraturan dan Pelaksanaan Undang-undang di Bidang Usaha Hukum Perusahaan Pemakaian Nama PT, Tata Cara Mendirikan PT, Pendaftaran Perusahaan, TDUP \& SIUP, Kesaint Blanc, Jakarta.

Munir Fuady, 2010, Doktrin-doktrin Modern dalam Corporate Law dan Eksistensinya dalam Hukum Indonesia, Cetakan Kedua, Citra Aditya Bakti, Bandung. , 2003, Perseroan Paradigma

Baru, Citra Aditya Bakti, Bandung. 
M. Yahya Harahap, 2011, Hukum Perseroan, Makalah

Catakan Ketiga, Edisi Ketujuh, Sinar Nindyo Pramono, Perbandingan Perseroan Grafika, Jakarta.

Remi Sutan Syahdeni, 2010, Hukum di Beberapa Negara, yang ditulis Kepailitan Memahami Undangundang Nomor 37 Tahun 2004 tentang Kepailitan, Cetakan Keempat, Edisi Baru, Pustaka Utama Grafiti, Jakarta.

Rudhi Prasetya, 2011, Perseroan Teori dan

Praktek, Sinar Grafika, Jakarta. dalam rangka pelaksanaan dan pengembangan sistem hukum nasional Badan Pembinaan Hukum Nasional Kementerian Hukum dan Hak Asasi Manusia R.I.

\section{Peraturan Perundang-undangan}

Undang-undang Nomor 40 Tahun 2000. 